\title{
Retrieving Semantic Information and Names of Proper and Common Nouns in People with and without Aphasia
}

\author{
Jae-Min Shin', Ji-Wan Ha ${ }^{\text {b }}$ Yu Mi Hwangc, Sung-Bom Pyun ${ }^{\mathrm{d}}$ \\ ${ }^{a}$ Department of Speech and Language Pathology, Graduate School of Rehabilitation Science, Daegu University, Gyeongsan, Korea \\ ${ }^{b}$ Department of Speech Pathology, Daegu University, Gyeongsan, Korea \\ ${ }^{c}$ Brain Convergence Research Center, Korea University College of Medicine, Seoul, Korea \\ ${ }^{d}$ Department of Physical Medicine and Rehabilitation, Korea University College of Medicine, Seoul, Korea
}

\author{
Correspondence: Ji-Wan $\mathrm{Ha}, \mathrm{PhD}$ \\ Department of Speech Pathology, Daegu \\ University, 201 Daegudae-ro, Jillyang-eup, \\ Gyeongsan 38453, Korea \\ Tel: $+82-53-850-4327$ \\ Fax: +82-53-850-4329 \\ E-mail: jw-ha@daegu.ac.kr
}

Received: January 20, 2020

Revised: February 10, 2020

Accepted: February 10, 2020

This research was supported by the R\&D grant (No. 2014005) on rehabilitation by Korea National Rehabilitation Center Research Institute, Ministry of Health \& Welfare.

\begin{abstract}
Objectives: The aim of this study was to determine whether performance differs between proper nouns and common nouns in semantic and naming tasks between patients with aphasia and normal adults. Methods: 20 patients with aphasia and 20 normal adults performed a proper noun semantic task, common noun semantic task, proper noun naming task, and common noun naming task. Following this, we compared the scores and analyzed the correlation among the four tasks. Results: The differences among the groups and the types of tasks were statistically significant, but not according to the noun types. Also, noun type and group interaction effect were not statistically significant; but task type and group, noun type and task type, and noun type, task type and group interaction effect were significant. In the aphasia group, there was a significant correlation between the performance of all tasks, and the correlation coefficient between the proper noun semantic task and the common noun semantic task was very high. Conclusion: In the aphasia group, we confirmed that the proper noun score was significantly better than the common noun when performing semantic tasks. This study suggests that in the case of proper nouns, the function of the right hemisphere; that is, the activation of visual information, may be involved in semantic processing. As a result, it suggests that aphasia patients with damaged left hemispheres were assisted in the process of proper noun semantics by using the uninjured right hemisphere.
\end{abstract}

Keywords: Left hemisphere damage, Aphasia, Semantic task, Naming task, Proper noun, Common noun
실어증은 언어습득 이후 뇌졸중과 같은 후천적인 대뇌 손상으로 발생하는 언어장애(McNeil \& Pratt, 2001)로, 말하기, 듣기, 읽기, 쓰 기 등 다양한 의사소통 활동에 어려움을 야기한다(Kim \& Na, 2001). 실어증이 발생하면 상대방의 말을 이해하지 못하거나 발화가 비유 창해지거나 따라말하기가 어려울 수 있고(Ryan, 1982), 흔히 실독 증과 실서증이 동반된다(Godefroy, Dubois, Debachy, Leclerc, \& Kreisley, 2002). 더불어 이름대기 장애(anomia)가 주요 증상으로 나타나는데, 이는 실어증 유형에 상관없이 모든 환자가 보이는 실어 증의 공통증상이기도 하다(Goodglass \& Kaplan, 1983).
이름대기 능력 평가에 가장 많이 이용되는 과제는 그림을 보여 준 후 그 그림에 해당하는 단어의 이름을 말하게 하는 대면 이름대 기 과제이며, 이때 사용된 단어는 대부분 보통명사이다. 이처럼 보 통명사가 평가항목으로 많이 사용되는 이유로, 보통명사의 경우 일반적인 사물의 이름이므로 검사 대상자들 대부분이 아는 참조 물(referent)일 가능성이 높고, 원형(prototype)이 존재하여 그림으 로 표현하기가 용이하기 때문인 점 등을 생각해볼 수 있다. 그러나 실어증 환자는 보통명사보다 고유명사에서 이름 인출에 더욱 어려 움을 보이며, 따라서 이들의 이름대기 능력을 보다 민감하게 평가 
하기 위해 고유명사 이름대기 과제의 중요성이 보고된 바 있다 (Beeson, Holland, \& Murray, 1997; Robson, Marshall, Pring, Montagu, \& Chiat, 2010). 불특정 다수를 대상으로 평가가 실시되어야 하는 만큼, 고유명사 중 검사 대상자들이 공통적으로 알고 있는 사 람, 즉, 유명인을 평가항목으로 많이 사용하고 있다. 유명인 이름대 기 평가는 높은 진단적 민감성으로 인해 원발진행형 실어증, 의미 치매, 경도인지장애 등 진행성 실어증 또는 인지.의사소통장애, 초 기 다른 검사로는 선별되지 않는 경미한 언어장애 증상을 판별하 는 데에도 유용한 것으로 보고되었다 $(\mathrm{Oh} \& \mathrm{Ha}, 2015)$.

그 사람이 어떤 사람인지, 무엇을 하는 사람인지와 같은 다양한 의미정보들은 떠올릴 수 있으나 정확한 이름 세 글자를 말하는 데 에 어려움을 직면하는 순간은 실어증 환자뿐 아니라 정상 노인들 도 많이 경험한다. 이 때 대부분의 사람들은 "알았는데 까먹었다", "입안에서 맴돈다" 등과 같은 표현을 하기도 하고, 기억을 해내려 고 노력하던 중 세 글자 중 한 글자 또는 두 글자를 기억해내기도 하 고, 혹은 한참 후 그 이름을 갑작스럽게 떠올리기도 한다. 이를 설단 현상(Tip-of-the-tongue phenomenon)이라고도 하는데, 설단현상 이란 표적단어에 대한 의미정보는 활성화되었지만 음운정보가 부 분적 또는 완전히 떠오르지 않는 증상을 말하며, 따라서 설단현상 은 음운정보산출의 실패를 잘 드러내주는 현상이라 할 수 있다 $(\mathrm{Oh}$ $\& \mathrm{Ha}, 2015)$. 고유명사는 설단현상을 유도하는 데에 매우 유용하 다(Oh \& $\mathrm{Ha}, 2015)$.

동일한 의미자질들을 공유하는 여러 참조물들이 하나의 의미부 류(class)로 묶여 그것이 하나의 이름(음운형태)과 연결되어 있는 보통명사와 달리, 고유명사는 하나의 참조물이 하나의 이름을 제 각각 가지고 있다(Thompson, Graham, Patterson, Sahakian, \& Hodges, 2002). 다시 말해 보통명사의 경우 옆집 개도, 그림 책에 나 오는 개도, 진돗개도, 누렁이도 모두 '개'라는 이름을 가지는 것에 반해, 고유명사는 내 친구 김미정만이 '김미정'이다. '김미정'과 의미 적 공통성이 매우 많은 또 다른 사람이 있더라도 그 사람은 전혀 다 른 이름을 가지고 있고, ‘김미정'이라는 동일한 이름을 가진 사람이 두 명이더라도 두 ‘김미정' 간에는 의미적 연관성이 없다. 따라서 고 유명사는 일반명사에 비해 의미정보와 음운정보의 연결이 무작위 적인 듯 보이며, 그로 인해 그 연결의 강도 또한 상대적으로 약할 수 밖에 없을 것이다. 또한 하나의 이름이 하나의 참조물에만 연결되 어 있기 때문에, 매우 친밀한 주변인이 아닌 다음 그 이름이 산출될 빈도 또한 보통명사보다 적을 가능성이 크다. 어휘인출 과정에서 이 전 단계의 활성화가 이후 단계의 활성화를 유도한다는 가설(Levelt, 1989)은 어휘인출의 각 단계들이 언어정보처리의 네트워크망 에 의해 서로 밀접하게 연결되어 있다는 전제 하에 가능한 것이다.
의미정보와 음운정보가 무작위적으로 연결되어 있고 그 빈도 또한 많지 않아 활성화의 기회가 적었을 고유명사의 경우, 이전 단계인 의미정보 활성화가 이후 단계인 음운정보 활성화를 유도할 가능성 이 보통명사보다 크지 않을 것으로 보인다. 이와 같은 이유로 의미 활성화부터 음운 활성화까지 순차적으로 이루어지는 이름대기 과 제에서 고유명사는 음운정보인출에 대해 더욱 부담이 큰 과제인 듯하다. 음운적 처리는 주로 좌반구에서 담당하기 때문에(Tremblay, Monetta, \& Joanette, 2004), 좌반구에 손상이 있는 실어증 환 자들이 음운처리에 결함을 보이고, 나아가 이들이 음운처리의 부 담이 큰 고유명사 인출에 더욱 어려움을 보이는 것은 당연한 것으 로 여겨진다.

반면 실어증 환자가 고유명사 인출에 어려움을 보인다는 앞에서 의 연구결과들과 대조적으로, 이들이 고유명사에 대한 재인능력 (recognition)은 보존하고 있다고 밝힌 연구들 또한 찾아볼 수 있다 (Goodglass, 1980; Kim, 2017; Van Lancker \& Klein, 1990; Ohnesorge \& Van Lancker, 2001). 특히 보통명사의 재인에는 매우 어려움 이 있는 심한 전실어증 환자가 사람 이름에 대해서는 말소리와 글 자 중 어떤 자극으로 제시하여도 모두 재인이 가능하였다는 연구 결과(Van Lancker \& Klein, 1990)로 인해 고유명사는 보통명사와 재인과정이 다를 가능성이 강하게 제기되었다. 이에 대해, 좌반구 에서 담당하는 언어재인은 보통명사라는 특정 범주에 한정된다는 가설(McNeil, Cipolotti, \& Warrington, 1994), 친밀함이라는 개인 적 경험은 우반구에서 담당하기 때문에 실어증 환자에서 주변사람 이름의 재인능력이 보존된다는 주장(Van Lancker \& Klein, 1990) 등이 제기되었다. 이와 관련하여 $\operatorname{Kim}$ (2017)은 실어증 환자들을 대 상으로 유명인에 대한 어휘접근 과제 실험을 실시하여, 앞에서의 가설들과는 또 다른 가능성을 제안하였다. 재인은 단어를 듣거나 보았을 때 그것의 의미를 파악하는 심리적 과정인데, 이 때 떠오르 는 의미들은 다양한 양식(modality)을 가진다. 크게는 언어적 의미 와 시각적 의미로 구분될 수 있는데, 사람의 경우 얼굴, 신체적 특징 등, 특히, 시각적 양상이 강할 것이다. 이는 시각처리를 담당하는 우 반구의 활성화, 특히, 우반구의 전두엽에서 발생하는 세타파를 촉 진하며(Kwon \& Lee, 2013), 따라서 사물보다 사람 이름의 처리에 우반구가 더욱 관여하게 되고, 이로 인해 좌반구가 손상된 실어증 환자도 사람 이름의 재인능력을 어느 정도 보존할 가능성이 있다. $\operatorname{Kim}$ (2017)은 실험항목으로 친밀한 주변인이 아닌 유명인 이름을 사용함으로써, 실어증 환자에서 사람 이름의 재인능력 보존이 Van Lancker와 Klein (1990)의 주장처럼 개인적 경험이라는 우반구 기 능의 영향만은 아님을 밝혔다. 또한 단어의 재인에 좌반구가 범주 특정적으로 관여한다는 McNeil 등(1994)의 다소 모호한 가설에 
대해서도 보다 구체적인 설명을 덧붙였다.

본 연구에서는 Kim (2017)의 제안을 토대로 좌반구 손상 실어증 환자를 대상으로 고유명사와 보통명사간 의미처리 능력이 다른지 를 살펴보고 이를 바탕으로 고유명사, 특히 사람 이름의 경우 의미 처리에 시각적 활성화가 보다 동반되는지, 즉 우반구가 더욱 관여 하는지를 확인하고자 하였다. 고유명사의 재인과정을 살펴보았던 선행연구들(Kim, 2017; Van Lancker \& Klein, 1990; Ohnesorge \& Van Lancker, 2001)과 달리, 본 연구는 고유명사의 의미처리에 초점 을 두어 그것을 보통명사와 비교하고자 한다. 이때, 앞에서 언급하 였던 것처럼, 고유명사와 보통명사 간에는 의미와 음운의 연결 강 도가 다를 수 있다. 때문에 재인연구에서 사용하였던 것과 동일한 방식, 즉 말소리나 글자 등의 언어자극에 대해 그것에 해당하는 참 조물을 선택하게 하는 실험과제를 사용할 경우 그 결과 해석에 제 한이 있을 것으로 보인다. 즉, 언어로 자극을 제시한 후 그것을 통해 의미활성화를 파악하는 것은 두 명사 간 음운이라는 매개변수를 통제하는 데에 한계가 있을 것이다. 더군다나 실험 대상자가 실어 증 환자들인 만큼, 그들이 본질적으로 가지고 있는 음운이라는 언 어적 처리의 결함이 실험 결과에 더욱 영향을 줄 가능성을 배제할 수 없다. 이에 본 연구에서는 각 명사의 참조물에 음운 매개 없이 직 접적으로 의미 활성화가 일어날 수 있도록, 말소리나 글자 대신 사 진(고유명사)과 그림(보통명사)을 자극물로 이용하기로 하였다. 본 연구가 특히 시각적 의미처리에 초점을 두고 있는 만큼 사진과 그 림 자극을 이용하여 대상자들의 의미처리능력을 평가하는 것은 타당한 방법으로 여겨진다. 또한 Levelt (1989)의 구어처리모델에 의하면 의미처리를 담당하는 개념화부(conceptualization)는 아직 언어로 형성되지 않은 개념들을 활성화시키는 전언어적(pre-verbal) 단계에 해당한다. 개념화부를 언어적 의미처리 과정으로 한정 하지 않았던 Levelt (1989)의 모델에 근거하더라도, 고유명사와 보 통명사의 의미 활성화를 유도하기 위해 자극물로 언어 대신 그림을 사용한 것은 문제가 없을 것으로 판단된다.

이와 관련하여, 그림 자극을 이용한 대표적인 의미지식 평가도구 로 국외에서 널리 사용되는 'Pyramids \& Palm Trees' (PPT; How$\operatorname{ard} \&$ Patterson, 1992)를 들 수 있다. PPT는 주어진 그림 또는 단어 자극과 의미적으로 관련이 있는 그림을 두 개의 보기 중에서 고르 는 검사로, 각 참조물 또는 단어로부터 의미와 개념정보를 인출하 는 능력, 그리고 그것을 의미적으로 관련 있는 또 다른 참조물과 연 결시키는 능력을 평가하는 도구이다. 자극과 보기 항목들이 모두 그림으로 제공되는 그림 하위검사의 경우 언어적 처리를 반드시 거 칠 필요가 없는 전언어적 혹은 비구어적(non-verbal) 의미지식 과 제라 할 수 있다. 본 연구에서는 PPT의 그림 하위검사와 유사한 방
식을 활용하여, 고유명사와 보통명사에 대한 의미정보 연결능력을 비교해보고자 하였다.

본 연구에서는 명사종류에 따른 의미정보 연결 수행력을 파악 하는 것과 더불어 음운정보의 처리과정까지 포함하는 어휘인출 과 제, 즉 이름대기 과제도 실시하여 과제유형에 따른 수행력 차이 또 한 알아보고자 하였다. 의미처리만을 포함하는 의미연결 과제와 의 미처리부터 음운처리까지 어휘인출의 전 과정을 포함하는 이름대 기 과제 간 수행력이 상이할 경우, 실어증 환자가 가지는 언어처리 과정의 각 단계 별 취약점의 경중도, 그리고 명사의 종류가 이에 미 치는 영향 등에 대해 시사하는 바가 있을 것이다. 정리하면, 본 연구 에서는 좌반구 손상 실어증 환자들이 의미연결 과제와 이름대기 과제에서 고유명사와 보통명사에 대한 수행력이 다르게 나타나는 지를 알아보고자 하였다. 이를 위해 고유명사 의미연결 과제, 보통 명사 의미연결 과제, 고유명사 이름대기 과제, 보통명사 이름대기 과제를 실시하여, 실어증 집단의 수행력을 정상 집단과 비교하였 다. 또한 실어증 집단에서 각 과제의 수행력 간 상관관계가 있는지, 그리고 그 정도는 어떠한지를 살펴보았다. 만일 실어증 집단의 수행 력이 과제유형 및 명사의 종류에 따라 다르게 나타난다면, 본 연구 결과는 뇌의 언어정보처리의 다양성, 그리고 더 나아가 실어증 환 자의 의미 및 음운능력 촉진을 위한 중재 시 유의할 점 등에 대해 의미 있는 정보를 제공할 것으로 기대한다.

\section{연구방법}

\section{연구대상}

본 연구의 대상자는 좌반구 뇌손상으로 인해 실어증으로 진단 받은 실어증 환자 20 명과 정상 성인 20 명의 총 40 명이었다. 실어증 을 야기한 뇌손상은 우세반구 전체 경로에 영향을 미치며(McNeil \& Pratt, 2001), 따라서 그로 인해 실어증 증상에 공통적인 특징인 이름대기 장애와 의미능력 손상이 발현된다(Burke, Mackay, Worthley, \& Wade, 1991). 이에 본 연구에서는 실어증 환자를 실어 증 하위유형 별로 분류하지 않고, 뇌졸중으로 인해 좌반구의 피질 또는 피질하에 손상이 초래되었고, 이로 인해 실어증이 발생한 환 자 전체를 하나의 실험집단으로 하여 연구를 진행하였다.

실어증 집단의 선정 기준은 첫째, 뇌졸중을 병인으로 하고, 둘째, 좌반구 피질 또는 피질하에만 병변을 가지며, 셋째, 파라다이스.한 국판 웨스턴 실어증 검사(Paradise Korean version-the Western Aphasia Battery, K-WAB; Kim \& Na, 2001) 결과에 근거하여 언어 재활사 및 재활의학과 전문의에 의해 실어증으로 진단받은 환자들 로, 넷째, 발병 후 최소 6 개월이 경과하였고, 다섯째, 초등학교 졸업 
Table 1. Descriptive information of participants with aphasia

\begin{tabular}{|c|c|c|c|c|c|c|}
\hline Number & Sex & Age (yr) & Education (yr) & РОТ & Aphasia type & $\mathrm{A} 0$ \\
\hline 1 & $\mathrm{~F}$ & 60 & 12 & 17.8 & Conduction & 83.0 \\
\hline 2 & M & 62 & 9 & 18.1 & Global & 20.3 \\
\hline 3 & M & 61 & 12 & 18.3 & Global & 18.9 \\
\hline 4 & M & 58 & 9 & 19.1 & Conduction & 72.6 \\
\hline 5 & $F$ & 26 & 12 & 17.1 & Anomic & 66.3 \\
\hline 6 & $\mathrm{~F}$ & 48 & 16 & 18.3 & Conduction & 69.8 \\
\hline 7 & $F$ & 59 & 12 & 16.9 & Broca & 47.2 \\
\hline 8 & M & 57 & 14 & 16.6 & Conduction & 59.7 \\
\hline 9 & M & 66 & 12 & 15.12 & Broca & 52.1 \\
\hline 10 & M & 63 & 9 & 18.8 & Broca & 38.4 \\
\hline 11 & $F$ & 57 & 9 & 17.4 & Global & 17.3 \\
\hline 12 & M & 61 & 12 & 16.3 & Wernicke & 56.5 \\
\hline 13 & M & 55 & 6 & 16.7 & Global & 7.4 \\
\hline 14 & $\mathrm{~F}$ & 79 & 9 & 16.8 & Conduction & 53.2 \\
\hline 15 & M & 76 & 12 & 17.3 & Anomic & 78.6 \\
\hline 16 & M & 68 & 6 & 18.9 & Broca & 32.4 \\
\hline 17 & M & 52 & 9 & 17.9 & Broca & 52.0 \\
\hline 18 & $\mathrm{~F}$ & 71 & 9 & 16.5 & Global & 10.0 \\
\hline 19 & $\mathrm{~F}$ & 32 & 16 & 18.2 & Anomic & 81.4 \\
\hline 20 & $\mathrm{~F}$ & 65 & 12 & 16.1 & Global & 17.8 \\
\hline
\end{tabular}

F=Female; $M=$ Male; Pot=Post-onset time; $\mathrm{A} 0=$ Aphasia quotient.

이상의 학력을 갖추고 있으며, 여섯째, 보호자 또는 환자의 보고에 근거하여 발병 전 오른손잡이고, 일곱째, 실어증 이외에 다른 정신 적, 신경학적 질병이 없고 청각 및 시각 기능이 정상범주에 속하는 자였다. 선정 과정에서 경미하더라도 연구과제의 올바른 수행이 염 려될 정도의 인지능력 저하가 관찰되거나 명료도가 심하게 떨어지 는 마비말장애 또는 말실행증 동반 환자는 제외하였다. 반면 실어증 지수(AQ)가 매우 낮은 전실어증 환자는 실험대상에 포함하였는데, 그 이유는 전실어증 환자의 경우도 유명인 또는 주변 사람에 대한 단어재인능력을 보존하고 있다는 선행연구(Kim, 2017; Ohnesorge \& Van Lancker, 2001; Van Lancker \& Klein, 1990)에 근거하여 본 연구의 실험과제 수행이 가능할 것으로 판단하였기 때문이다. 본 연구의 실험 집단인 실어증 환자들의 기본 정보는 Table 1 과 같다.

정상 집단은 첫째, 한국판 간이정신상태검사(Korean-Mini Mental State Examination, K-MMSE; Kang, Na, \& Hahn, 1997)를 실시하여 정상 범주(연령 및 교육년수 대비 $16 \%$ ile 이상)에 속하는 자, 둘째, 언어 및 인지기능과 관련한 신경학적 손상을 경험한 적이 없는 자, 셋째, 실어증 집단과 평균연령, 교육년수 및 성별이 일치하 는 자를 대상자로 선정하였다. 실어증 집단과 정상 집단 간 연령, 교 육년수 및 성별의 차이를 알아보기 위해 독립표본 $t$-검정과 Chisquare 검정을 실시하였고, 그 결과 연령, 교육년수, 성별에 두 집단
간 유의한 차이가 없음을 확인하였다( $p>.05)$.

\section{연구도구}

고유명사 실험과제

고유명사항목 선정

고유명사 의미연결 및 이름대기 과제의 항목을 제작하기 위해 $\mathrm{Oh}$ 와 $\mathrm{Ha}$ (2015) 그리고 Kim (2017)의 연구의 유명인 명사목록을 참고하였다. Oh와 $\mathrm{Ha}$ (2015) 그리고 Kim (2017)은 성인 및 노인 실 험대상자들이 TV 등의 각종 매체를 접한 영향이 있고, 대부분이 잘 알고 있는 유명인들로 1970 년대에서 2000년대의 유명인 실험단 어를 한정하였고, 이를 위해 현대국어 사용빈도 조사(Cho, 2002), 시사저널과 포브스 코리아의 1989-2012년 한국사회 영향력 있는 인물 TOP 10 자료 등을 참고하여 고빈도 고유명사 후보목록을 선 정하였다. 그 후 정상 성인들을 대상으로 후보목록에 대한 적절성 설문조사를 실시하여, 그 결과를 바탕으로 실험에 사용될 유명인 목록을 최종 결정하였다. 본 연구에서는 $\mathrm{Oh}$ 와 $\mathrm{Ha}$ (2015) 그리고 $\operatorname{Kim}$ (2017) 연구에서 중복되는 유명인을 포함한 총 40 명의 유명인 을 고유명사 실험과제 항목으로 선정하였다. 선정된 유명인의 직업 은 연예인(방송인) 또는 작가 15 명, 운동선수 13 명, 정치인 또는 사 업가 12 명이었다.

이후 선정된 모든 유명인에 대해 구글 이미지 검색 등을 이용하 여 실험에 적절한 사진을 확보하였으며, 이 때 실험용 인물사진 선 택 기준은 다음과 같았다(McKenna \& Warriongton, 1980). 첫째, 사진의 인물이 명확하게 구별 가능해야 하고, 둘째, 하나의 시각적 자극(사진)에 대해 하나의 반응(유명인 이름)만을 유도할 수 있어 야 하고, 셋째, 의상, 악세서리 등 해당 유명인에 대해 단서가 될 만 한 정보가 없어야 하고, 넷째, 과거 인물이라도 시대와 상관없이 사 람들이 쉽게 알아볼 수 있어야 한다. 사진은 얼굴이 크게 나온 상반 신만을 포함하였고, 크기는 가로 $7.58 \mathrm{~cm}$ 와 세로 $10 \mathrm{~cm}$ 의 사이즈 로 모든 항목이 동일하게 제작되었다.

\section{고유명사의미연결 과제}

고유명사 의미연결 과제는 제시된 유명인 사진과 의미적으로 관 련 있는 그림을 두 개의 보기 중에서 선택하는 과제이다. 관련 그림 (정답)은 유명인의 직업, 별명 혹은 대표되는 이미지로, 비 관련 그 림(오답)은 범주만 일치시키고 유명인과 연관이 없는 이미지로 설 정하였다. 본 과제에서 가장 중요한 것은 유명인과 정답에 해당하 는 목표 그림 자극 간 의미적으로 명확한 연결관계가 있어야 한다 는 점이다. 때문에 목표 그림이 해당 유명인과 의미적으로 얼마나 연관이 있는지에 대해 1 급 또는 2 급 자격증을 소지한 언어재활사 


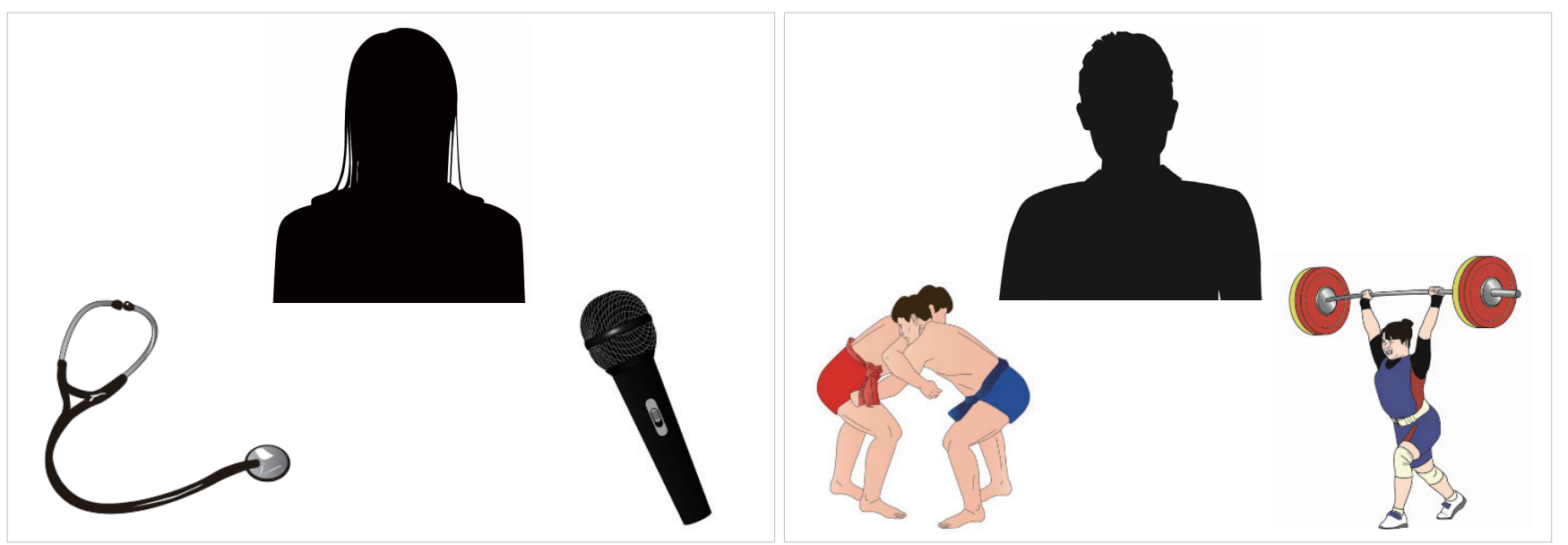

Figure 1. The examples of the semantic task of proper nouns.

25인에게 설문조사를 실시하였다. 설문은 특정 사이트(http://naver.me/Ixw7qaul)에서 온라인 설문방식으로 진행되었으며, 40 개의 항목 각각에 대해 5점 척도(1: 전혀 연관이 없다, 2: 연관이 없다, 3: 보통이다, 4: 연관이 있다, 5: 매우 연관이 있다)에서 답변을 선택하 도록 하였다. 그 결과 모든 항목에 대해 4점 이상의 점수를 받았으 며, 40개 전체 항목에 대한 평균 연관성은 4.39(범위: 4.19-5.00)였 다. 따라서 모든 항목에서 유명인과 목표 그림 간에는 의미적으로 관련성이 있음을 확인하였다.

고유명사 의미연결 과제의 보기 그림은 보통명사 의미지식 과제 (Hwang \& Pyun, 2015)의 그림작업을 하였던 동일한 일러스트레이 터에게 의뢰하여 제작하였다. 보통명사 의미지식 과제와 같은 그림 형식으로 작업을 해줄 것을 요청하였으며, 모든 그림이 해당 단어 의 대표적 의미를 잘 표현해야 하는 만큼 연구자들 및 주변 언어재 활사들로부터 그림타당도에 대한 피드백을 받아 여러 차례 수정 작업을 거쳐 완성하였다. 모든 그림은 색상을 입혀 제작되었고, 대 표적 의미를 한 개의 사물 또는 인물 그림으로 표현하고자 노력하 였으나(Figure 1 의 좌측 예시), 그것이 어려운 경우 두 세 개의 개념 에 해당하는 그림을 포함하였다. 예를 들어 씨름을 표현하기 위해 '샅바’만을 제작하였으나 그림타당도를 조사해 본 결과 예상과 달 리 '샅바' 이외에 다양한 답변이 관찰되어, 씨름에는 '씨름선수'와 '샅바’를, 역도에는 ‘역도선수'와 ‘역기'를 그려 넣었다(Figure 1의 우 측 예시).

전체 과제는 파워포인트 문서로 제작되었다. 상단에는 유명인 사 진을, 하단 왼쪽과 오른쪽에는 두 개의 보기 그림을 배치하였고, 보 기 그림 중 정답과 오답의 위치는 무작위로 하였다. 항목 제시 순서 는 유명인의 시대, 범주, 한글 자음, 고빈도 순서와 무관하게 무작위
로 제시되도록 하였다. 이와 같은 고유명사 의미연결 과제의 예시는 Figure 1과같다.

\section{고유명사이름대기 과제}

고유명사 이름대기 과제는 아무런 단서 없이 유명인 사진을 보고 그 사람의 이름을 말하는 과제이다. 목표어가 고유명사 의미연결 과제의 자극어(유명인)와 동일하기 때문에, 고유명사 의미지식 과 제와 동일한 유명인 사진 자극을 사용하였다. 그러나 단서가 제공 되지 않기 때문에, 의미지식 과제와 달리 보기 그림 없이 화면 전체 에 유명인 사진 한 장만 제시되어 있다.

\section{보통명사 실험과제}

보통명사의미연결 과제

보통명사 의미연결 과제는 Hwang과 Pyun (2015)이 개발한 의미 지식 검사(가칭 “토끼와 거북이 검사”)의 항목을 그대로 사용하였 다. Hwang과 Pyun (2015)의 의미지식 검사는 국외에서 널리 사용 되는 의미지식 검사인 Pyramids and Palm trees test (Howard \& Patterson, 1992), The Camel and Cactus test (Bozeat, S., Lambon Ralpha, M. A., Patterson, K., Garrard, P., \& Hodges, J. R., 2000) 등 을 참고하여 한국의 문화와 실정에 맞게끔 항목과 그림을 개발하 고, 정상인 및 뇌손상 환자들을 대상으로 표준화작업을 마친 국내 최초의 의미지식 검사도구이다. 해당 검사는 그림 의미지식 검사와 단어 의미지식 검사의 두 가지 하위검사로 구성되어 있으며, 여러 선행연구들(Cho, Ha, Hwang, \& Pyun, 2015; Ryu, 2018; Kim 2018) 에서 일반 아동, 단순언어장애 아동, 실어증 환자 등 다양한 유형의 대상자들을 대상으로 그 타당성이 입증된 바 있다. 아직 출판 전이 


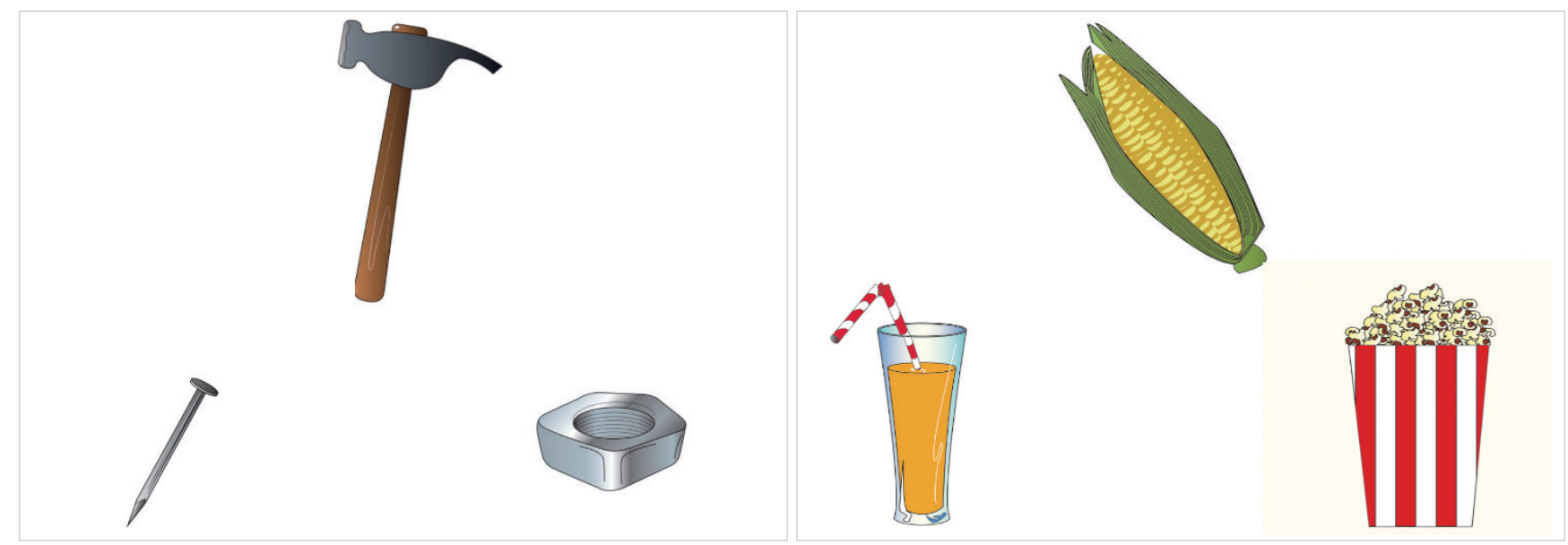

Figure 2. The examples of the semantic task of common nouns (from Hwang \& Pyun, 2015).

기 때문에 연구자들이 표준화 작업에서 사용하였던 검사틀과 기 록지를 참고하여, 그림 의미지식 하위검사의 전체 60 개 항목 중 40 개를 본 연구의 의미연결 과제 항목으로 사용하였다. 선정된 항목 의 범주는 자연물 18 개(장미꽃, 사슴, 파인애플, 무궁화, 포도, 펭귄, 갈매기, 늑대, 토끼, 옥수수, 금붕어, 당근, 호박, 소나무, 벌, 손, 바나 나, 귀), 인공물 16 개(침대, 드라이버, 한복, 망치, 버스, 텔레비전, 소 파, 톱, 기차, 우산, 엘리베이터, 탬버린, 칼, 책상, 싱크대, 도끼), 추상 물 6개(의사, 요리사, 수영, 농부, 권투, 스키)였다.

고유명사 의미연결 과제 방식과 동일하게 상단에는 보통명사에 해당하는 사물, 사람 등의 그림을, 하단 왼쪽과 오른쪽에는 두 개의 보기 그림을 배치하였고, 보기 그림 중 정답과 오답의 위치는 무작 위로 하였다. 항목 제시 순서는 단어의 빈도와 범주와 무관하게 무 작위로 제시되도록 하였다. 이러한 보통명사 의미연결 과제의 예시 는 Figure 2와 같다.

\section{보통명사이름대기 과제}

보통명사 이름대기 과제는 아무런 단서 없이 그림을 보고 그 그 림에 해당하는 이름을 말하는 과제이다. 목표어가 보통명사 의미연 결 과제의 자극어와 동일하기 때문에, 의미지식 과제의 자극어 그 림과 동일한 것을 사용하였다. 그러나 단서가 제공되지 않기 때문 에, 의미지식 과제와 달리 화면 전체에 보기 그림 없이 자극 그림 한 장만 제시되어 있다. 고유명사 이름대기의 경우 목표 단어인 유명인 이름이 모두 3 음절로 이루어져 있기 때문에, 보통명사도 가급적이 면 3음절로 이루어진 단어들을 선택하고자 하였다. 그러나 이는 현 실적으로 불가능하여 2음절 또는 3 음절로 이루어진 단어를 주로 선 택하였고, 1 음절, 4 음절, 5 음절 단어도 일부 포함하였다. 최종 선택
된 전체 40 개 단어의 평균 음절길이는 2.25 (표준편차 0.88 )이었다.

\section{연구절차}

본 실험에 앞서 연구를 진행하는 데에 절차 상의 문제가 없는지 를 점검하기 위해, 청년층(25세), 중년층(45세), 노년층(62세) 각각 1 명씩, 총 3 명의 정상 성인을 대상으로 예비 실험을 실시하였다. 사전 검사 없이 본 연구의 실험과제만을 진행하는 데에 대상자 1 명 당 20 여분의 시간이 소요되었다. 이름대기 후 의미연결 과제를 실시하였 는데, 이는 의미연결 과제를 먼저 실시할 경우 보기로 제시된 관련 또는 비 관련 그림이 해당 어휘의 인출에 촉진 또는 방해효과를 일 으킬 가능성을 배제하기 위함이었다. 예를 들어, 고유명사를 먼저 실시한 경우 고유명사 이름대기, 보통명사 이름대기, 고유명사 의미 연결, 보통명사 의미연결 순으로, 보통명사를 먼저 실시한 경우는 보통명사 이름대기, 고유명사 이름대기, 보통명사 의미연결, 고유명 사 의미연결 순으로 과제를 진행하였다. 이러한 절차로 진행한 예비 실험에서 별다른 문제점이 관찰되지 않았기 때문에, 본 실험도 이 와 동일하게 진행하도록 하였다.

본 실험은 조용한 환경에서 개별적으로 진행하였고, 사전검사를 모두 마친 후 실험과제를 실시하였다. 실험과제 제시 순서에 의한 차이를 배제하기 위해, 각 집단에서 대상자 10 명은 보통명사 과제 를, 나머지 10 명은 고유명사 과제를 먼저 실시하도록 하였다. 실험 이 시작되기에 앞서 명사종류 별 2개의 연습문항을 먼저 실시하였 고, 실험이 진행되는 동안 대상자들의 모든 반응을 I-Phone $6 \mathrm{~S}$ 에 녹음하면서 반응기록지에 기록하였다. 실험 순서는 예비실험과 동 일하였다. 이름대기 과제에서는 사진 또는 그림을 보자마자 곧바로 해당 이름을 말하여야 한다. 그러나 즉시 답변을 하지 못한 경우 대 
상자의 반응을 15 초까지 기다렸으며, 자가수정(self-correction) 시 마지막 반응을 기록하였다. 의미연결 과제에서는 고유명사 사진 또 는 보통명사 그림과함께 보기 그림이 하나의 화면에 동시에 제공된 다. 대상자는 해당 화면을 보면서 제시된 고유명사 또는 보통명사 와 의미적으로 가장 관련이 있는 그림을 보기 중에서 선택하여 손 으로 가리켜야 한다. 이 때에도 대상자의 반응을 15 초까지 기다렸 으며 자가수정 시 마지막 반응을 기록하였다.

\section{자료분석 및 통계분석}

의미연결 과제는 의미적으로 연관 있는 정답 그림을 선택한 경우 에만 정반응으로 점수화하였고, 각 문항 당 1점씩, 명사종류(고유명 사, 보통명사) 별 각각 40 점 만점이 되도록 하였다. 이름대기 과제는 사진 또는 그림을 보고 정확한 이름을 답한 경우에만 정반응으로 점수화하였고, 마찬가지로 각 문항 당 1점씩, 명사종류(보통명사, 고 유명사) 별 각각 40 점 만점이 되도록 하였다. 마비말장애 또는 말실 행증으로 인해 경미한 말소리 오류를 보인 경우, 방언을 사용한 경 우 등은 무시하였으나, 명백한 음소착어는 오반응으로 처리하였다.

통계분석은 SPSS ver. 23.0 (Statistical Package for the Social Science)을 사용하였다. 모든 변수 간 상호작용효과가 있는지 확인하 기 위해, 각 과제유형 또는 명사종류 별로 반복적으로 집단 간 비교 를 실시하는 대신 모든 변수를 한꺼번에 투입한 후 혼합설계에 따 른 분산분석을 실시하였다. 즉, 집단(실어증 집단, 정상 집단) 간 과 제유형(의미연결 과제, 이름대기 과제) 및 명사종류(고유명사, 보통 명사)에 따른 통계적 차이를 알아보기 위해, 1피험자 간-2피험자 내 혼합설계에 따른 반복측정 분산분석을 실시하였다. 유의한 상호작 용 효과에서는 COMPARE syntax를 입력하여 사후검정을 실시하 였다. 상관관계 분석은 실어증 집단에서만 실시하도록 하였는데, 그 이유는 정상 집단의 경우 네 가지 실험과제 모두에서 별 어려움 이 없이 만점에 가까운 점수가 나올 것이 예상되었기 때문이다. 따 라서 실어증 집단에서 네 가지 실험과제 점수 간 Pearson 적률상관 분석을 실시하였다.

\section{연구결과}

\section{집단 간 과제유형 및 명사종류에 따른 정반응 수행력}

과제유형 및 명사종류에 따른 각 과제 별 두 집단의 정반응 점수 는 Table 2 와 같다. 정상 집단은 네 과제 모두에서 거의 만점(40점) 에 가까운 점수를 받아 큰 어려움 없이 모든 과제를 수행하였음을 알 수 있다. 반면 실어증 집단은 정상 집단보다 모든 과제에서 수행 력이 낮았는데, 의미연결 과제보다 이름대기 과제를 더 어려워하였
Table 2. Descriptive statistics of scores in the experimental tasks

\begin{tabular}{lcc}
\hline & Aphasic ( $\mathrm{N}=20)$ & Normal (N=20) \\
\hline The semantic task of proper nouns & $33.60(7.12)$ & $39.60(0.60)$ \\
The semantic task of common nouns & $31.55(7.76)$ & $39.70(0.57)$ \\
The naming task of the proper nouns & $15.15(11.38)$ & $39.55(0.89)$ \\
The naming task of common nouns & $18.30(11.77)$ & $39.70(0.73)$ \\
\hline
\end{tabular}

Values are presented as mean (SD).

다. 실어증 집단에서 명사종류와 관련하여 한 가지 흥미로운 점은 의미연결 과제의 경우 보통명사보다 고유명사를 더 잘했던 것에 반 해, 이름대기 과제에서는 그 반대의 양상이 나타났다는 것이다.

이러한차이에 대해 통계적으로 분석한 결과, 집단간차이 $\left(F_{(1,38)}=\right.$ $63.511, p<.001)$ 및 과제유형에 따른 차이 $\left(F_{(1,38)}=76.199, p<.001\right)$ 는 통계적으로 유의하였으나, 명사종류에 따른 차이는 유의하지 않았다 $\left(F_{(1,38)}=.448, p>.05\right)$. 즉, 실어증 집단은 정상 집단보다 점수 가 유의하게 떨어졌고, 이름대기 과제가 의미연결 과제보다 유의하 게 어려웠음을 알 수 있다. 또한 명사종류와 집단 간 상호작용효과 는 통계적으로 유의하지 않았으나 $\left(F_{(1,38)}=.177, p>.05\right)$, 과제유형과 집단 간 $\left(F_{(1,38)}=5.720, p<.001\right)$, 명사종류와 과제유형 간 $\left(F_{(1,38)}=\right.$ $12.177, p<.01)$, 그리고 명사종류, 과제유형과 집단 간 $\left(F_{(1,38)}=11.717\right.$, $p<.01)$ 상호작용효과가 모두 유의하였다.

유의한 상호작용효과에 대해 사후검정을 실시한 결과, 과제유형 의 경우 실어증 집단은 이름대기 과제를 의미연결 과제보다 유의하 게 어려워하였으나 $(p<.001)$ 정상 집단은 두 과제 간 수행력 차이가 없었고 $(p>.05)$, 명사종류의 경우 의미연결 과제에서 고유명사가 보 통명사 점수보다 유의하게 좋았으나 $(p<.01)$ 이름대기 과제에서는 두 명사 간 차이가 유의하지 않았다 $(p>.05)$. 집단, 명사종류, 과제 유형 간 3 요인 상호작용효과에 대해서는, 실어증 집단의 의미연결 과제에서 고유명사의 점수가 유의하게 좋았던 반면 $(p<.01)$, 실어 증 집단의 이름대기 과제 및 정상 집단의 이름대기와 의미연결 과 제에서는 명사 간 유의한 차이가 나타나지 않았다 $(p>.05)$. 실어증 집단의 경우 이름대기 과제에서 명사종류 간 차이가 평균적으로는 매우 두드러졌는데, 이는 이름대기 과제의 표준편차가 상대적으로 컸기 때문에 나타난 결과로 보인다. 이와 같은 3 요인 상호작용효과 의 결과를 정리하면, 고유명사와 보통명사 간 유의한 차이는 실어 증 집단이 의미연결 과제를 수행할 때에만 드러나는 것임을 알 수 있다(Figure 3).

\section{실어증 집단에서 각 과제 수행력 간 상관관계}

실어증 집단에서 명사종류 및 과제유형에 따른 네 가지 실험과 제의 수행력 간 상관관계를 구하였으며, 그 결과 모든 과제 간 상관 


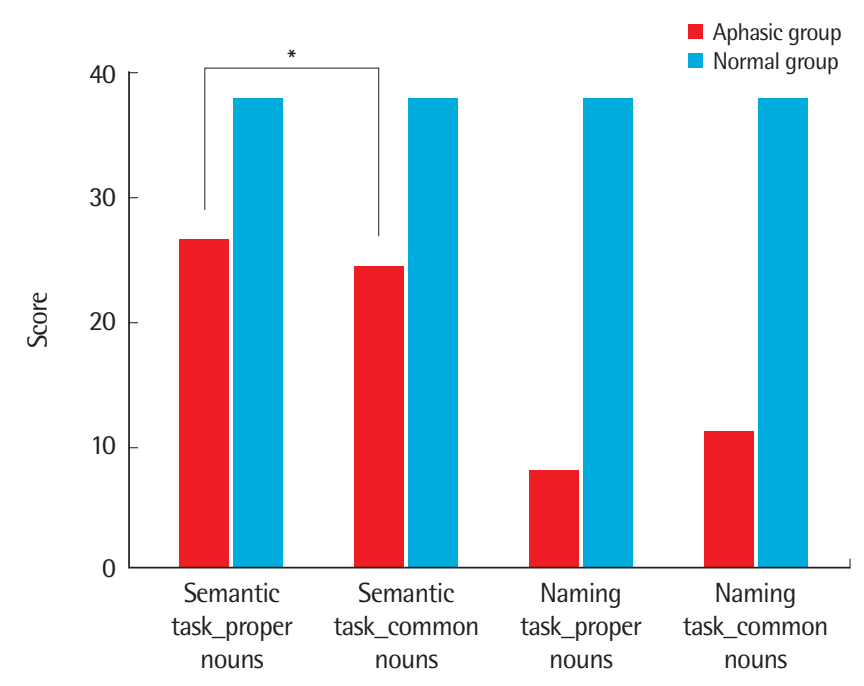

Figure 3. The semantic and naming task performances by noun types in aphasic and normal groups.

${ }^{*} p<.05$.

관계가 유의한 것으로 나타났다 $(p<.05, p<.01)$ (Table 3). 상관계 수에 대해서는 의미연결 과제의 경우 고유명사와 보통명사 간 .935 의 매우 높은 상관을 보인 반면, 의미연결과 이름대기 과제 간에는 보통명사-고유명사, 고유명사-고유명사 사이에 상관계수가 .532와 .579 로 그 정도가 가장 낮았다. 그 밖에 나머지 과제 간에는 상관계 수.675부터.795 사이로, 상관 정도가 높은 편이었다.

\section{논의 및 결론}

본 연구에서는 좌반구 손상 실어증 환자와 정상 성인들을 대상 으로 의미연결 과제와 이름대기 과제에서 고유명사와 보통명사에 따라 수행력에 차이가 있는지를 알아보았다. 그 결과 집단 간 차이 및 과제유형에 따른 차이는 통계적으로 유의하였으나, 명사종류에 따른 차이는 유의하지 않았다. 또한 명사종류와 집단 간 상호작용 효과는 통계적으로 유의하지 않았으나, 과제유형과 집단 간, 명사 종류와 과제유형 간, 그리고 명사종류, 과제유형과 집단 간 상호작 용효과가 모두 유의하였다. 정상 집단의 경우 어려움 없이 모든 과 제를 수행하여 네 과제 모두에서 평균적으로 만점에 가까운 점수 를 받았기 때문에(Table 2 참고), 집단 간 차이가 유의하였던 것은 당연한 결과로 보인다. 그 보다는 집단 내 및 집단 간 변수들의 상호 작용효과에 대해 보다 심층적인 논의가 필요할 것이다.

우선 실어증 집단에서 이름대기 과제의 수행력이 의미연결 과제 의 수행력보다 유의하게 떨어졌다. 서론에서도 설명하였듯이 이름 대기는 의미부터 음운까지의 언어의 전 처리과정을 요구하는 과제
Table 3. The correlation among four tasks in the aphasic group

\begin{tabular}{|c|c|c|c|c|}
\hline & \multicolumn{2}{|c|}{ The semantic task } & \multicolumn{2}{|c|}{ The naming task } \\
\hline & $\begin{array}{l}\text { Proper } \\
\text { nouns }\end{array}$ & $\begin{array}{c}\text { Common } \\
\text { nouns }\end{array}$ & $\begin{array}{l}\text { Proper } \\
\text { nouns }\end{array}$ & $\begin{array}{c}\text { Common } \\
\text { nouns }\end{array}$ \\
\hline \multicolumn{5}{|l|}{ The semantic task } \\
\hline \multicolumn{5}{|l|}{ Proper nouns } \\
\hline Common nouns & $.935^{* *}$ & & & \\
\hline \multicolumn{5}{|l|}{ The naming task } \\
\hline Proper nouns & $.579 * *$ & $.532^{*}$ & & \\
\hline Common nouns & $.675^{* *}$ & $.720^{* *}$ & $.795^{* *}$ & \\
\hline
\end{tabular}

${ }^{*} p<.05,{ }^{* *} p<.01$.

로, 의미연결 과제와 달리 음운처리의 부담감이 더해져 과제 수행 력이 급격하게 떨어졌음을 알 수 있다. 음운처리는 좌반구에서 주 로 담당하기 때문에(Tremblay, Monetta, \& Joanette, 2004), 좌반구 가 손상된 실어증 집단에서 음운처리과정을 포함하는 이름대기의 수행력이 유의하게 떨어진 것은 타당한 결과로 여겨진다. 더불어 이 름대기 과제에서 보통명사보다 고유명사의 점수가 평균적으로 낮 았다는 본 연구의 결과로 인해(Table 2), 고유명사 인출은 음운정보 처리능력을 더욱 요구하는 과제(Oh \& Ha, 2015)임을 다시 한 번 확 인할 수 있었다. ‘음운처리’는 매우 광범위한 용어로, 그 손상은 다 양한 증상을 야기할 수 있다. 베르니케 실어증의 경우 어휘집에서 음운표상 인출에 실패하여 신조어의 형태로 단어를 산출할 수 있 고(Goddglass, 1980), 전도 실어증의 경우 음운단기기억력의 손상 으로 들었던 발화를 똑같이 따라하는 데에 어려움을 보일 수 있고 (Goodglass \& Kaplan, 1983), 브로카 실어증의 경우 음운부호화 (phonological encoding)의 결함으로 구어산출에 제한을 받을 수 있다(Nixon, Lazaroya, Hodinott-Hill, Gough, \& Passingham, 2004). 좌반구 내 특정 국소영역에서 특정 음운처리기능을 담당할 수는 있지만, 의사소통활동에서 요구되는 음운처리기능은 매우 다양하다. 따라서 실어증 유형 및 좌반구 뇌손상 영역에 따라 ‘음운 처리'의 과정에서 나타난 손상이 다를 수 있으나, 공통적으로 음운 처리에 취약점을 보이고, 그로 인해 본 연구에서도 실어증 환자들 이 고유명사 인출에 가장 큰 어려움을 보였을 것이다.

또한 본 연구결과 실어증 집단에서 의미연결 과제 수행 시 고유 명사의 점수가 보통명사보다 유의하게 좋다는 것을 확인할 수 있었 다. 이는 좌반구가 손상된 실어증 환자에서 고유명사의 의미적 처 리는 손상되지 않은 우반구에서 담당하기 때문이라는 선행연구들 (Chiarello, 1991; Kim, 2017; Ohnesorge \& Van Lancker, 2001)과 그 맥락을 같이 한다. 또한 우반구가 고유명사의 의미처리를 담당하는 이유로, 유명인의 경우 의미정보에 시각적 정보가 많이 포함되어 있 기 때문이라는 $\operatorname{Kim}$ (2017)의 가설을 지지하는 결과이기도 하다. 그 
러나 여기에서 간과하면 안 되는 것은 보통명사보다 고유명사 과제 점수가 유의하게 높기는 하였으나, 여전히 정상 집단보다는 그수행 력이 떨어졌다는 점이다. 더군다나 본 연구의 의미연결 과제가 언어 적 처리과정을 반드시 거칠 필요가 없는 비구어적 그림 과제라는 것을 감안할 때 실어증 환자들이더라도 손상되지 않은 우반구 기 능 즉, 양호한 시각적 처리능력을 활용하여 충분히 정상인들만큼 과제를 수행할 가능성도 예상해볼 수 있으나 연구결과 그러지 못 하였다. 의미처리는 좌반구 또는 우반구가 전적으로 관여하여는 것 이 아니라 좌반구와 우반구가 연합적으로 관여한다는 선행연구

(Chiarello, 1985; Chiarello, Burgess, Richards, \& Pollock, 1990; Michimata \& Hellige, 1987), 언어적 의미정보와 시각적 의미정보 가 서로 활발하게 상호작용한다는 가설(Warrington \& Shallice, 1984) 등을 상기할 때, 고유명사의 경우도 이에 예외가 아닐 수 있 음을 생각해볼 수 있다. 정리하면 실어증 환자들이 고유명사의 의 미처리에 양호한 시각기능의 도움을 더 많이 받았음은 틀림없지 만, 의미처리에 있어 그것이 사진이나 그림과 같은 시각적 자극일지 라도, 언어의 영향을 전적으로 배제할 수는 없는 듯하다. 이는 우반 구 기능을 보존하고 있는 실어증 환자에서 의미연결 과제의 수행 이, 서론에서 언급한 것처럼, 시각적 활성화를 통해 고유명사에서 더 양호한 것으로 나타났으나, 정상인 집단에 비해 어려움을 보인 것은 우반구의 독립적인 역할만으로는 과제 수행에 한계가 있음을 시사한다.

뿐만 아니라 실어증 집단의 의미연결 과제에서 고유명사와 보통 명사 간 유의한 차이가 있었지만, 고유명사의 점수가 보통명사보다 월등히 높지는 않았다. 이에 대해서는 방법 상의 제한점을 생각해볼 수 있다. 고유명사 의미연결 과제에서 자극물은 유명인의 사진이었 으나, 보기 항목들은 유명인과 의미적으로 관련이 있거나 혹은 없는 보통명사들(마이크, 청진기)에 대한 그림이었다(Figure 1). 즉, 고유 명사 과제임에도 불구하고 그 과제를 수행하기 위해서는 보통명사 에 대한 의미처리능력이 요구되었다는 것을 부정할 수 없다. 보통명 사의 의미처리를 좌반구의 기능으로 보고한 여러 선행연구들(Chiarello, 1991; McNeil et al., 1994)에 근거할 때, 이러한 과제의 방법적 특성이 손상된 좌반구에 부담을 주었고, 그로 인해 명사종류 간 수 행력에 두드러진 차이가 나타나지 않았을 수 있다.

상관관계 분석 결과 실어증 집단에서 모든 과제 수행력 간 유의 한 상관이 있었는데, 그 중 동일한 과제유형인 의미연결 과제 내에 서 고유명사와 보통명사 간 상관이 매우 높은 것으로 나타났다 $(r=.935$, Table 3). 실어증 환자들에서 손상된 언어기능의 양상은 매우 다양하며, 각 하위 언어 영역 별로 상이한 특성을 보이기도 한 다. 또한 실어증 환자의 경우 개인차가 매우 크기 때문에 실어증 환
자들을 하나의 집단으로 묶어 그 증상의 보편적 양상을 찾기란 쉽 지 않다. 이와 같은 실어증 집단의 특성 상 행동실험에서 상관계수 .935는 매우 높은 수치로, 이러한 결과가 나타난 이유로 손상된 좌 반구가 전적으로 의미처리를 담당하지 않았기 때문이다. 즉, 시각 적 의미연결 과제의 의미처리에 손상되지 않은 우반구가 중요한 역 할을 하였기 때문임을 다시 한 번 생각해볼 수 있다. 이와는 대조적 으로 동일한 품사인 고유명사 내에서 의미연결 과제와 이름대기 과 제 간 상관은 그리 높지 않았다 $(r=.579$, Table 3). 서론에서 언급하 였듯이, 고유명사는 어휘적 특성 상 의미정보와 음운정보 간 연결 강도가 보통명사보다 강하지 않을 수 있다. 때문에 실어증 환자에 따라 의미 또는 음운단계의 선택적 손상 또는 보존의 가능성을 생 각해볼 수 있으며, 그로 인해 이와 같은 결과가 초래되었을 수 있다. 덧붙이자면 고유명사는 보통명사에 비해 의미와 음운적 처리능력 을 좀 더 분리해서 파악할 수 있다는 매우 독특한 특성을 가지고 있 다. 즉, 고유명사는 좌반구 손상 실어증 환자에게 의미적으로는 쉬 우나 음운적으로는 어려운 단어인 반면, 우반구 손상 환자의 경우 그 반대의 가능성을 생각해볼 수 있다. 따라서 고유명사는 의사소 통장애 환자에게 매우 유용한 평가 또는 중재 항목으로 사용될 수 있을 것이다.

마지막으로 본 연구결과에 근거하여 실어증 환자의 어휘중재 시 고려해야 할 점을 제안해보고자 한다. 언어기능이 손상된 실어증 환자일지라도 고유명사, 특히 사람에 대한 의미정보는 상대적으로 보존하고 있을 수 있다. 그러므로 의미능력 증진을 위해서는 보통 명사보다 고유명사부터 시작하는 것이 바람직할 것이다. 정도가 심 한 환자의 경우 사진 또는 그림과 같은 비구어 시각 자극을 활용하 여 해당 참조물에 대한 의미 활성화를 유도해보는 것도 좋은 방법 일 수 있다. 이와 관련하여 손상되지 않은 전언어적 단계의 활성화 가 이후 손상된 언어 단계의 촉진을 유도할 수 있다는 선행연구 (Levelt, Roelofs, \& Meyer, 1999)에서도 그 근거를 찾을 수 있다. 그 러나 고유명사에 대한 의미의 촉진이 바로 어휘인출로 연결되기는 쉽지 않은 듯하다. 어휘인출의 경우 고유명사보다 보통명사를 활용 하는 것이 즉각적인 효과를 유도하기에 더 용이할 수 있으며, 고유 명사에 대한 인출을 성공시키기 위해서는 음운정보를 촉진하기 위 한 별도의 전략이 필요할 것으로 판단된다. 또한 좌반구 내에서 좀 더 세부적으로 분류한 병소에 따라 이와 같은 가설에 차이가 있는 지에 대해서도 추후 연구에서 확인해 볼 필요가 있을 것이다.

\section{REFERENCES}

Beeson, P. M., Holland, A. L., \& Murray, L. L. (1997). Naming famous people: 
an examination of tip-of-the tongue phenomena in aphasia and Alzheimer's disease. Aphasiology, 11(4-5), 323-336.

Bozeat, S., Lambon Ralpha, M. A., Patterson, K., Garrard, P., \& Hodges, J. R. (2000). Non-verbal semantic impairment in semantic dementia. Neuropsychologia, 38(9), 1207-1215.

Burke, D., Mackay, G., Worthley, J. \& Wade, E. (1991). On the tip of tongue: What causes word finding failures in young and older adults?. Journal of Memory and Language, 30(5), 542-579.

Chiarello, C. (1985). Hemisphere dynamics in lexical access: automatic and controlled priming. Brain and Language, 26(1), 146-172.

Chiarello, C. (1991). Interpretation of word meanings by the cerebral hemispheres: One is not enough. In P. J. Schwanenflugel (Ed.), The Psychology of Word Meanings (pp. 251-278). Hills dale, NJ, US: Lawrence Erlbaum Associates, Inc.

Chiarello, C., Burgess, C., Richards, L., \& Pollock, A. (1990). Semantic and associative priming in the cerebral hemispheres: some words do, some words don't ... sometimes, some places. Brain and Language, 38(1), 75-104.

Cho, E. J., Ha, J. W., Hwang, Y, M., \& Pyun, S. B. (2015). Application of semantic knowledge test for four- to six-year-old children. The proceedings of the joint conference of The Korean Academy of Speech-Language Pathology \& Audiology and Korean Speech-Language \& Hearing Association, 210211.

Cho, N. H. (2002). Frequent use in modern Korean Research. Seoul; National Institute of the Korean Language.

Godefroy, O., Dubois, C., Debachy, B., Leclerc, M., \& Kreisley, A. (2002). Vascular aphasias: Main characteristics of patients hospitalized in acute stroke units. Stroke, 33(3), 702-705.

Goodglass, H. (1980). Disorders of naming following brain injury. American Scientist, 68(6), 647-655.

Goodglass, H., \& Kaplan, E. (1983). The assessment of aphasia and related disorders (2nd ed.). Philadelphia, PA; Lea \& Febiger.

Howard, D., \& Patterson, K. (1992). Pyramids and Palm Tress Test. Bury St Edmunds: Tames Valley Test Company.

Hwang, Y. M., \& Pyun, S. B, (2015). The development semantic knowledge test: "Rabbit and Tuttle Test". The proceedings of the joint conference of The Korean Academy of Speech-Language Pathology \& Audiology and Korean Speech-Language \& Hearing Association, 208-209.

Kang, Y. W., Na, D. L., \& Hahn, S. H. (1997). A validity study on the Korean mini-mental state examination (K-MMSE) in dementia patients. Journal of the Korean Neurological Association, 15(2), 300-308.
Kim, H. H., \& Na, D. R. (2001). Paradise Korean version-Western Aphasia Battery (K-WAB). Seoul; Paradise.

Kim, S. J. (2018). A comparative study on semantic knowledge capability of normal children and children with specific language impairment (Master's thesis). Daegu University, Gyeongsan, Korea.

Kim, Y. J. (2017). A study on the semantic approach task performance according to noun and modality types between aphasiac and normal groups (Master's thesis). Daegu University, Gyeongsan, Korea.

Kwon, Y. S., \& Lee, K. J. (2013). The effects of science and art integrated program on brain activity of gifted students in science. The Korean Society of Elementary Science Education. 32(4), 567-580.

Levelt, W. J. (1989). Speaking: from intention to articulation. Cambridge, MA: The MIT Press.

Levelt, W. J. M., Roelofs, A., \& Meyer, A. S. (1999). A theory of lexical access in speech production. Behavioral and Brain Sciences, 22(1), 1-38.

McKenna, P. \& Warrington, E. K. (1980). Testing for nominal dysphasia. Journal of Neurology, Neurosurgery, Psychiatry, 43(9), 781-788.

McNeil, J. E., Cipolotti, L., \& Warrington, E. K. (1994). The accessibility of proper names. Neuropsychologia, 32, 193-208.

McNeil, M. R., \& Pratt, S. R. (2001). Defining aphasia: some theoretical and clinical implications of operating from a formal definition. Aphasiology, 15(10-11), 901-912.

Michimata, C., \& Hellige J. B. (1987). Effects of blurring and stimulus size on the lateralized processing of nonverbal stimuli. Neuropsychologia, 25(2), 397-407.

Nixon, P., Lazarova, J., Hodinott-Hill, I., Gough, P., \& Passingham, R. (2004). The inferior frontal gyrus and phonological processing: an investigation using rTMS. Journal of Cognitive Neuroscience, 16(2), 289-300.

Ohnesorge, C., \& Van Lancker, D. (2001). Cerebral laterality for famous proper nouns: visual recognition by normal subjects. Brain and Language, 77(2), 135-165.

Oh, S. A., \& Ha, J. W. (2015). The effects of aging and mild cognitive impairment on the tip-of-the-tongue phenomenon in people naming task. Dementia and Neurocognitive Disorders, 14(1), 39-47.

Robson, J., Marshall, J., Pring, T., Montagu, A., \& Chiat, S. (2010). Processing proper nouns in aphasia: Evidence from assessment and therapy. Aphasiology, 18(10), 917-935.

Ryan, W. J. (1982). The nurse and the communicatively impaired adult. New York; Springer Publishing Company.

Ryu, J. G. (2018). A study on performance of semantic knowledge test in apha- 
sia patients corresponding to modalities of stimuli and semantic category (Master's thesis). Daegu University, Gyeongsan, Korea.

Thompson, S. A., Graham, K. S., Patterson, K., Sahakian, B. J., \& Hodges, J. R. (2002). Is knowledge of famous people disproportionately impaired in patients with early and questionable Alzheimer's disease?. Neuropsychology, 16(3), 344-358.
Tremblay, T., Monetta, L., \& Joanette, Y. (2004). Phonological processing of words in right- and left-hangers. Brain and Cognition, 55(3), 427-432.

Van Lancker, D., \& Klein, K. (1990). Preserved recognition of familiar personal names in global aphasia. Brain and Language, 39(4), 511-529.

Warrington, E. K., \& Shallice, T. (1984). Category specific semantic impairment. Brain, 107(3), 829-853. 


\section{국문초록}

\section{실어증 집단과 정상 집단 간 고유명사와 보통명사의 이름대기 및 의미연결 수행력 비교}

신재민 ${ }^{1}$ 하지완 ${ }^{2}$ 황유미 ${ }^{3} \cdot$ 편성범 ${ }^{4}$

${ }^{1}$ 대구대학교 재활과학대학원 언어치료학과, ${ }^{2}$ 대구대학교 언어치료학과, ${ }^{3}$ 고려대학교 융합뇌신경연구소, ${ }^{4}$ 고려대학교 의과대학 재활의학교실

배경 및 목적: 본 연구에서는 좌반구 손상 실어증 환자와 정상 성인들을 대상으로 의미연결 과제와 이름대기 과제에서 고유명사와 보 통명사에 따라 수행력에 차이가 있는지를 알아보았다. 방법: 좌반구 손상 실어증 환자와 정상 성인 각 20 명을 대상으로, 고유명사 의미 연결, 보통명사 의미연결, 고유명사 이름대기, 보통명사 이름대기 과제를 실시하여 정반응 점수를 비교하였고, 실어증 집단에서 각 과제 의 수행력 간 상관관계가 어떠한지 분석하였다. 결과: 집단 간 차이 및 과제유형에 따른 차이는 통계적으로 유의하였으나, 명사종류에 따른 차이는 유의하지 않았다. 또한 명사종류와 집단 간 상호작용효과는 통계적으로 유의하지 않았으나, 과제유형과 집단 간, 명사종류 와 과제유형 간, 그리고 명사종류, 과제유형과 집단 간 상호작용 효과가 모두 유의하였다. 실어증 집단에서 모든 과제 수행력 간 유의한 상관이 있었고, 그 중 고유명사 의미연결 과제와 보통명사 의미연결 과제의 상관계수가 매우 높은 것으로 나타났다. 논의 및 결론: 실어 증 집단에서 의미연결 과제 수행 시 고유명사의 점수가 보통명사보다 유의하게 좋다는 것을 확인하였다. 본 연구는 고유명사의 경우 우 반구의 기능, 즉 시각정보의 활성화가 의미처리에 관여할 가능성, 그로 인해 좌반구가 손상된 실어증 환자가 손상되지 않은 우반구를 활용하여 고유명사 의미처리에 도움을 받았을 가능성을 제시하고 있다.

핵심어: 좌반구 손상, 실어증, 의미연결, 이름대기, 보통명사, 고유명사

본 연구는 보건복지부 국립재활원 재활연구개발용역사업(No. 2014005)으로 수행되었습니다.

\section{참고문헌}

강연욱, 나덕렬, 한승혜(1997). 치매환자들을 대상으로 한 K-MMSE의 타당도 연구. 대한신경학회지, 15(2), 300-308.

권영식, 이길재(2013). 과학과 미술 통합프로그램이 초등과학영재의 뇌 활성에 미치는 효과. 초등과학교육, 32(4), 567-580.

김수진(2018). 일반아동과 단순언어장애아동의 의미지식 능력 비교. 대구대학교 재활과학대학원 석사학위논문.

김유진(2017). 실어증집단과 정상집단의 명사종류 및 자극양식에 따른 의미접근과제 수행력 연구. 대구대학교 대학원 석사학위논문.

김향희, 나덕렬(2001). 파라다이스·한국판 웨스턴 실어증 검사. 서울: 파라다이스 복지재단.

류재경(2018). 실어증 환자의 자극양식 및 의미범주에 따른 의미지식과제 수행력 연구. 대구대학교 대학원 석사학위논문.

조남호(2002). 현대 국어 사용빈도조사: 한국어 학습용 어휘 선정을 위한 기초조사. 서울: 국립국어연구원.

조은주, 하지완, 황유미, 편성범(2015). 의미지식 검사의 적용: 4세, 5세, 6세 일반아동을 대상으로. 2015 한국언어청각임상학회. 한국언어치료학회 공

동학술대회 자료집, 210-211.

황유미, 편성범(2015). 의미지식 검사의 개발: 가칭 “토끼와 거북이 검사”. 2015 한국언어청각임상학회. 한국언어치료학회 공동학술대회 자료집, 208-

209.

\section{ORCID}

신재민(제1저자, 언어재활사 https://orcid.org/0000-0001-8438-0220); 하지완(교신저자, 부교수 https://orcid.org/0000-0002-1191-791X); 황유미(공동저자, 연구교수 https://orcid.org/0000-0002-8994-7406); 편성범(공동저자, 교수 https://orcid.org/0000-0002-3471-9692) 